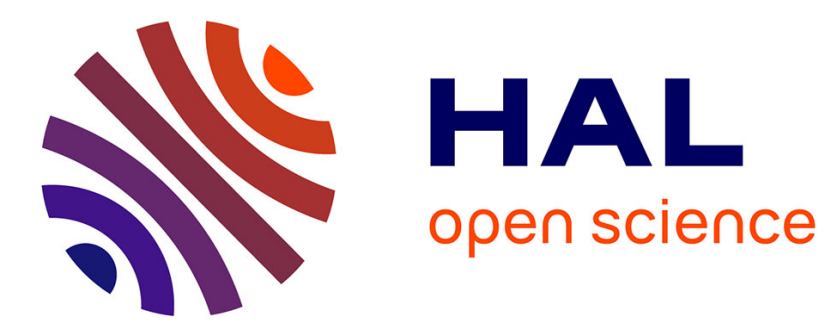

\title{
Pumpkin (Cucurbita moschata Duchesne ex Poir.) Seeds as an Anthelmintic Agent?
}

\author{
Carine Marie-Magdeleine, Maurice Mahieu, Harry Archimède
}

\section{To cite this version:}

Carine Marie-Magdeleine, Maurice Mahieu, Harry Archimède. Pumpkin (Cucurbita moschata Duchesne ex Poir.) Seeds as an Anthelmintic Agent?. Nuts and Seeds in Health and Disease Prevention, Chapitre 110 (1st Ed.), Academic Press - Elsevier, 2011, 978-0123-756-886. hal-02810473

\section{HAL Id: hal-02810473 https://hal.inrae.fr/hal-02810473}

Submitted on 6 Jun 2020

HAL is a multi-disciplinary open access archive for the deposit and dissemination of scientific research documents, whether they are published or not. The documents may come from teaching and research institutions in France or abroad, or from public or private research centers.
L'archive ouverte pluridisciplinaire HAL, est destinée au dépôt et à la diffusion de documents scientifiques de niveau recherche, publiés ou non, émanant des établissements d'enseignement et de recherche français ou étrangers, des laboratoires publics ou privés. 


\section{Provided for non-commercial research and educational use only. Not for reproduction, distribution or commercial use.}

This chapter was originally published in the book Nuts and Seeds in Health and Disease

Prevention. The copy attached is provided by Elsevier for the author's benefit and for the benefit of the author's institution, for non-commercial research, and educational use. This includes without limitation use in instruction at your institution, distribution to specific colleagues, and providing a copy to your institution's administrator.

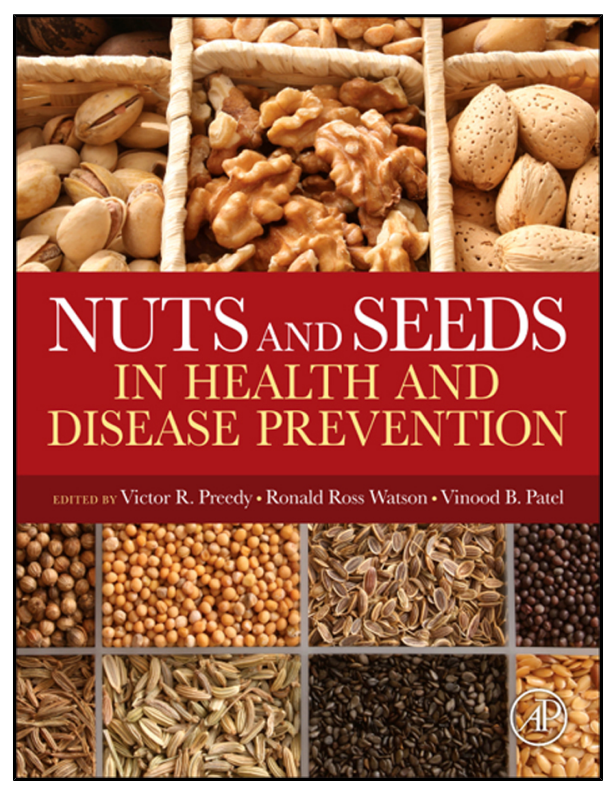

All other uses, reproduction and distribution, including without limitation commercial reprints, selling or licensing copies or access, or posting on open internet sites, your personal or institution's website or repository, are prohibited. For exceptions, permission may be sought for such use through Elsevier's permissions site at:

http://www.elsevier.com/locate/permissionusematerial

From Marie-Magdeleine, C, Mahieu, M, Archiméde, H. (2011). Pumpkin (Cucurbita moschata

Duchesne ex Poir.) Seeds as an Anthelmintic Agent?. In V. R. Preedy, R. R. Watson, V. B.

Patel (Editors), Nuts \& Seeds in Health and Disease Prevention (1st ed.) (pp 933-939). London, Burlington, San Diego: Academic Press is an imprint of Elsevier.

ISBN: 9780123756886

Copyright (C) 2011 Elsevier Inc. All rights reserved

Academic Press 


\section{Pumpkin (Cucurbita moschata Duchesne ex Poir.) Seeds as an Anthelmintic Agent?}

Carine Marie-Magdeleine, Maurice Mahieu, Harry Archimède

INRA, UR143 Unité de Recherches Zootechniques, Centre INRA-Antilles-Guyane, Domaine de Duclos, Petit-Bourg, Guadeloupe (French West Indies)

\author{
CHAPTER OUTLINE \\ Introduction 933 \\ Botanical Description 933 \\ Historical Cultivation and \\ Usage 934 \\ Present-Day Cultivation and \\ Usage 935
}

Applications to Health Promotion and Disease Prevention 936 Adverse effects and reactions (allergies and toxicity) 938 Summary Points 938

References 938

\section{INTRODUCTION}

The tropical America native pumpkin Cucurbita moschata (Figure 110.1) belongs to the Cucurbitaceae family (Fournet, 2002). The fruit is used as a vegetable, and the seed is a high energy source ( $40-50 \%$ lipids and $30-37 \%$ proteins in dry embryo material) which is consumed throughout the world with increasing popularity (Table 110.1; Leung et al., 1968; Caili et al., 2006). It is a valuable source of potassium, phosphorus, iron, and $\beta$-carotene (TRAMIL, 1999; Caili et al., 2006). The pumpkin seed is used as a vermifuge, galactogogue, and anti-emetic, and to treat various other medical issues, including prostate and bladder problems, in several countries (Caili et al., 2006). It contains a wide range of bioactive compounds, some of which could possess anthelmintic properties, prompting further experimental studies (Figure 110.2).

\section{BOTANICAL DESCRIPTION}

Cucurbita moschata is an annual dicotyledonous vegetable, with creeping or climbing stems (growing up to $5 \mathrm{~m}$ ) bearing tendrils. The stems are strong, cylindrical or pentangular, with petioles measuring $12-30 \mathrm{~cm}$. The stems and leaves are mildly hairy. The leaves are circular, kidney-shaped, heart-shaped, or triangular, often deeply indented at the base, weakly lobed, 


\section{PART 2}

Effects of Specific Nuts and Seeds

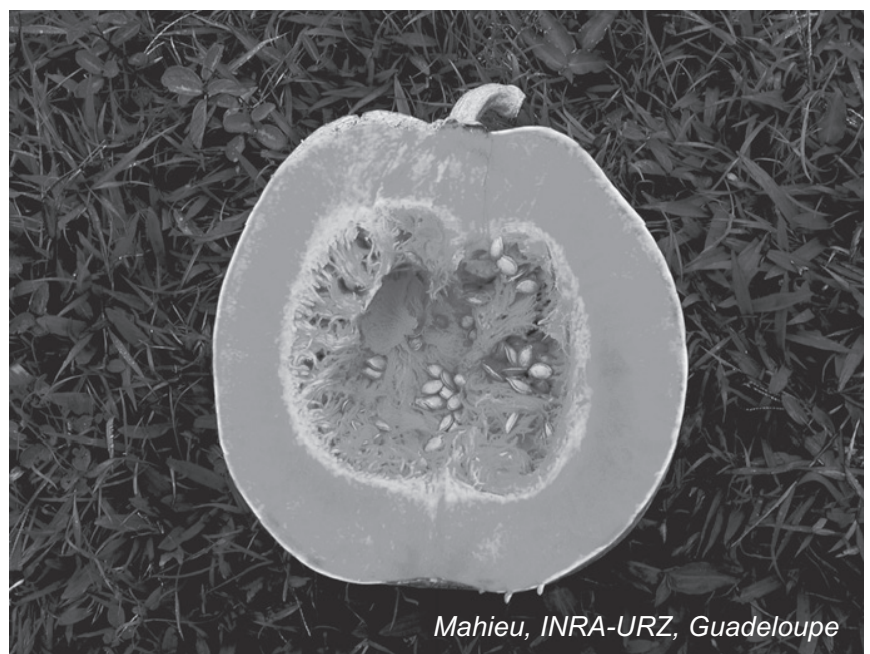

FIGURE 110.1

Longitudinal section of pumpkin Cucurbita moschata Duchesne ex Poir. The flesh is orange, and the hollow center contains pulpy loose fibers and flat, oval white seeds.

wavy and toothed, more or less white spotted, up to $20 \mathrm{~cm}$ long and $30 \mathrm{~cm}$ wide. The flowers are large, yellow, bell-shaped, five-lobed, and up to $12 \mathrm{~cm}$ long. The peduncle is strong, with a rounded pentangular base and large apex. Fruits are round, oblate, oval, oblong, or pearshaped, variously ribbed, $15-60 \mathrm{~cm}$ in diameter, and weigh up to $45 \mathrm{~kg}$. Their flesh is deep yellow, orange, pale green, or white, and the hollow center contains pulpy loose fibers and numerous seeds. The seeds (Figure 110.1) are oval, flat, white to brown, thin-shelled, irregularly margined, with a meaty kernel (Morton, 1981; Fournet, 2002).

\section{HISTORICAL CULTIVATION AND USAGE}

C. moschata is believed to be native to tropical America (Morton, 1981), where it has been used as a popular vegetable in cooking for several thousands of years. The seeds are edible, and have medicinal applications. In Austria and adjacent countries, pumpkins have been grown for oil production for about three centuries (Caili et al., 2006). C. moschata has been used traditionally as a medicine in many countries, including China, Yugoslavia, Argentina, India, Mexico, Brazil, and America (Caili et al., 2006). The anthelmintic activity of the seeds of the

\begin{tabular}{lc} 
TABLE 110.1 & $\begin{array}{c}\text { Cucurbita moschata Seed: Chemical } \\
\text { Composition for } \mathbf{1 0 0} \text { g of Husked Seeds }\end{array}$ \\
Constituent & \multicolumn{1}{c}{ Amount } \\
\hline Water & $5.5 \mathrm{~g}$ \\
Energy & $2331 \mathrm{~kJ}(555 \mathrm{kcal})$ \\
Proteins & $23.4 \mathrm{~g}$ \\
Lipids & $46.2 \mathrm{~g}$ \\
Carbohydrates & $21.5 \mathrm{~g}$ \\
Fibre & $2.2 \mathrm{~g}$ \\
Ca & $57 \mathrm{mg}$ \\
P & $900 \mathrm{mg}$ \\
Fe & $2.8 \mathrm{mg}$ \\
Thiamine & $0.15 \mathrm{mg}$ \\
Niacine & $1.4 \mathrm{mg}$ \\
\hline
\end{tabular}

Data from Leung et al. (1968). 


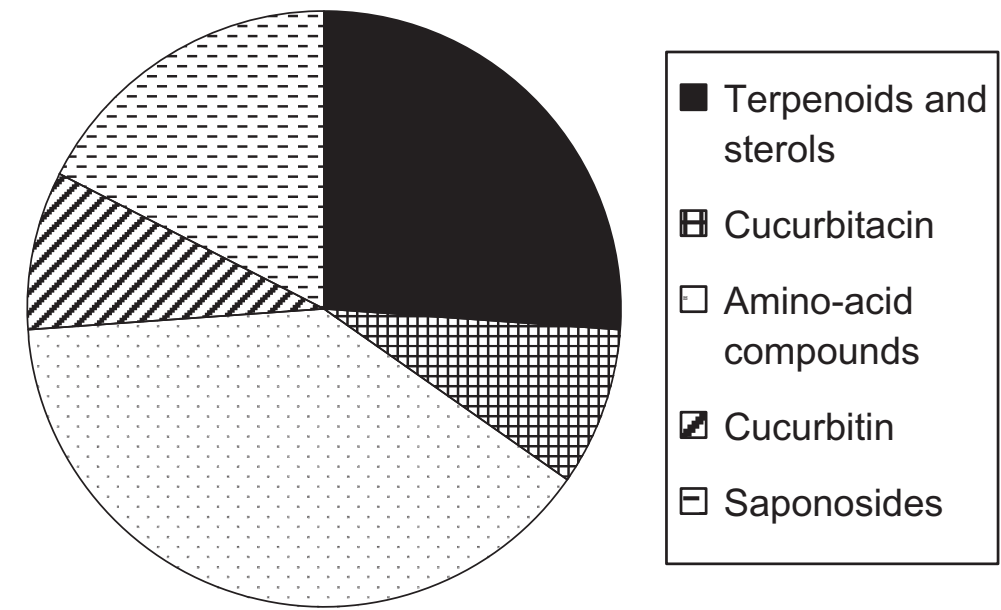

\section{FIGURE 110.2}

Qualitative phytochemical composition of Cucurbita moschata seed, suspected to have anthelmintic activity. The phytochemical determination was performed by thin layer chromatography methods. Qualitative composition and quantitative evaluation were assessed according to the intensity of the obtained spots. Data from Marie-Magdeleine (2009), PhD thesis.

Cucurbita species has long been known (Fang et al., 1961). The Surinam and Cherokee Amerindians used pumpkin seed as an anthelmintic, and also as a pediatric urinary aid to treat bed-wetting (Vogel, 1990).

\section{PRESENT-DAY CULTIVATION AND USAGE}

Nowadays, C. moschata represents an economically important vegetable species, commonly cultivated worldwide (Taylor \& Brant, 2002). The cultivation characteristics are summarized in Table 110.2.

C. moschata seeds are eaten in several countries as snacks, following salting and roasting (Koike et al., 2005). They are commonly used for treating diabetes, prostate gland disorders, and parasites. Data from the ethno-pharmacological literature indicate that $C$. moschata seeds are a potential vermifuge. Eaten fresh or roasted, they help relieve abdominal cramps and distension due to intestinal worms (Caili et al., 2006). Pumpkin seeds are also an important traditional Chinese medicine in the treatment of cestodiasis, ascariasis, and schistosomiasis (Koike et al., 2005). Seeds are used in the Middle East as an effective taenifuge (Karamanukian, 1961). In Middle America, a vermifugal preparation containing shelled and powdered pumpkin seeds is used to expel intestinal worms, including tapeworms (Morton, 1981).

\section{TABLE 110.2 Cucurbita moschata Cultivation Characteristics}

\section{Plant Needs}

Location

Plant density

Temperature

Period of growth

Soil

Sensitivity

\section{C. moschata Constraints}

Tropical countries, up to $1800 \mathrm{~m}$ altitude $2-3 \mathrm{~kg}$ of seed/ha, $2-4$ seeds per hill; planting distance $2 \mathrm{~m} \times 2 \mathrm{~m}$

Temperature above $20^{\circ} \mathrm{C}$ (day) and $14^{\circ} \mathrm{C}$ (night). Photoperiod-insensitive, year-round crop, but better growth during rainy season, if without irrigation. Not very demanding with respect to soil conditions; can be cultivated on fertile and well-drained soil, pH 5.5-6.8.

Drought-tolerant, but sensitive to frost and water-logging; excessive humidity stimulates fungal and bacterial development 


\section{PART 2}

Effects of Specific Nuts and Seeds

\section{APPLICATIONS TO HEALTH PROMOTION AND DISEASE PREVENTION}

Over the years, scientists have studied the many pharmacological actions and potential uses of pumpkin and its extracts. Clearly, there is a lot to learn about the health effects of this plant. Popular medicinal uses of pumpkin seeds have motivated experimental studies on their anthelmintic properties. Such studies have been conducted on different helminth models, and have produced conclusions that call for further research.

Veen and Collier (1949) showed the efficacy of an aqueous extract of the seeds of C. moschata as an anthelmintic in humans. Methylene chloride and methanolic extracts of $C$. moschata seed were evaluated on Caenorhabditis elegans, and showed no efficacy at the tested doses (Atjanasuppat et al., 2009). Beloin et al. (2005) reported anthelmintic activity against Caenorhabditis elegans at $500 \mu \mathrm{g} / \mathrm{ml}$. Marie-Magdeleine et al. (2009) showed that aqueous, methanolic, and dichloromethane extracts of C. moschata seed greatly inhibited ( $>90 \%)$ larval development of Haemonchus contortus in vitro. The dichloromethane and methanolic extracts had a marked effect on adult worm motility in vitro (inhibition of motility $>59 \%$ after $24 \mathrm{~h}$ of incubation). Atjanasuppat et al. (2009) evaluated the activity of methylene chloride and methanolic extracts of $C$. moschata seeds against Paramphistomum epiclitum, and found no efficacy at the tested doses. Seeds administered per os at a dose of $80 \mathrm{~g} /$ person showed high antischistosomial activity (TRAMIL, 1999). Clinical trials in Thailand confirmed that seed extracts were effective against schistosomes and tapeworms (Grubben \& Denton, 2004). The use of aqueous extracts of pumpkin seeds in the treatment of puppies experimentally infected with heterophyasis gave promising results, with even better results when combining extracts of areca nut and pumpkin seeds than when giving either extract alone. An effect was reported at the minimum inhibitory concentration of $23 \mathrm{~g}$ of pumpkin seeds in $100 \mathrm{ml}$ of distilled water in preclinical studies (Caili et al., 2006).

Some of the bioactive compounds present in the pumpkin seeds thus appear to possess anthelmintic properties, prompting further studies. Pumpkin seed oil contains $9.5-13 \%$ palmitic, $6-7.93 \%$ stearic, $0.04 \%$ arachidic, $37-39 \%$ oleic, and $44 \%$ linoleic acid. The seed also contains a wide range of bioactive compounds.

The vermifugal active principle of pumpkin seeds has for many years eluded a large number of investigators (Mihranian \& Abou-Chaar, 1968). In 1931, it was shown that this bioactive compound is soluble in $75 \%$ ethanol but not in petroleum ether, that it is dialyzable, and that its activity is reduced by boiling in dilute sulfuric acid. In 1937, it was also established that the compound is soluble in water and heat resistant. A purified deproteinized aqueous extract of the seeds of C. moschata was used as an anthelmintic in humans by Veen and Collier (1949). In 1961, after a comparative morphological, historical, and clinical study (Mihranian \& AbouChaar, 1968), it was found that pharmacologically active strains of pumpkin seeds should be administered in doses of about $500 \mathrm{~g}$.

The secondary metabolites suspected to be responsible for anthelmintic activity in C. moschata seed (Marie-Magdeleine, 2009; Marie-Magdeleine et al., 2009) are a triterpenic compound named cucurbitacin B, a non-proteic amino acid named cucurbitin (3-amino-pyrrolidine3-carboxylic acid), saponins, and sterols (Mihranian \& Abou-Chaar, 1968; TRAMIL, 1999), but other compounds might also be involved, such as cucurmosin, a ribosome-inactivating protein present in the sarcocarp of the pumpkin and also in the seed (Morton, 1981). Researchers are currently working on the structural properties and function of bioactive compounds of pumpkin (Caili et al., 2006) in order to elucidate their modes of action.

The role of non-proteic amino acids in plants is to protect seeds by intoxicating predators via an antimetabolite action; interference between non-proteic and normal amino acids during the biosynthesis of proteins by the predator causes toxicity because the enzymatic system of the 
predators cannot distinguish these non-proteic amino acids from the normal amino acids, due to their isostery. Consequently, the proteins biosynthesized by the predator may not be functional.

The non-proteic amino acid cucurbitin, which is only present in the seeds $(0.4-0.84 \%$ of the whole seed; Mihranian \& Abou-Chaar, 1968), has been focused on as the active principle responsible for anthelmintic, notably taenicidal and schistosomicidal, activity (Fang et al., 1961). Cucurbitin is also used as an anti-allergen for the preparation of cosmetics and pharmaceutical, particularly dermatological, products. The chemical structure of this amino acid is shown in Figure 110.3A.

In 1965, a study of the amino acids of the Cucurbitaceae in several species of Cucurbita (in Mihranian \& Abou-Chaar, 1968) revealed that cucurbitin was present in all species examined. A further study by Mihranian and Abou-Chaar (1968) confirmed that it appears to be confined to the genius Cucurbita, a matter of chemotaxonomic importance. Cucurbitin was associated with a large number of free amino acids in the seed. The free water-soluble amino acid cucurbitin was isolated from C. moschata seed, and showed inhibition of the growth of immature Schistosoma japonicum in vivo (Fang et al., 1961). Preliminary human research conducted in China and Russia has shown that it may also help in the treatment of tapeworm infestations (Plotnikov et al., 1972). Nevertheless, a high dose of cucurbitin appears to be necessary for efficient anthelmintic action (Mihranian \& Abou-Chaar, 1968).

The chemical structure of the cucurbitin compound is similar to that of the nematicidal compound named kainik acid (Figure 110.3B). Kainik acid has a neurodegenerative action on nematodes by substituting for glutamate. The analogy in chemical structure may underlie the similar mode of action of cucurbitin as an anthelmintic (Marie-Magdeleine et al., 2009). Several methods of detection, quantitative determination, and extraction of this amino acid from pumpkin seeds have been used: a two-dimensional paper chromatographic method, a separation method on ion-exchange cellulose phosphate paper, and HPLC and gas chromatography-mass spectrometry (Fang et al., 1961; Mihranian \& Abou-Chaar, 1968; Schenkel et al., 1992).

Despite the focus on cucurbitin as the active principle, other secondary metabolites present in the seeds of $C$. moschata might be considered as anthelmintics.

The ribosome-inactivating protein (RIP) cucurmosin is a RNA N-glycosidase that inactivates ribosomes via site-specific deadenylation of the large ribosomal RNA (Marie-Magdeleine et al., 2009). Ribosome-inactivating proteins are also capable of inactivating many non-ribosomal nucleic acid substrates. Some RIPs are able to promote antitumor or antiviral activities. The cucurmosin RIP, which may be present in the seed, could also have an

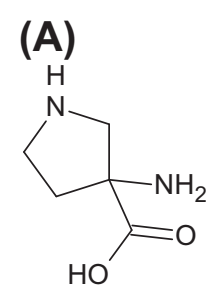

Cucurbitin

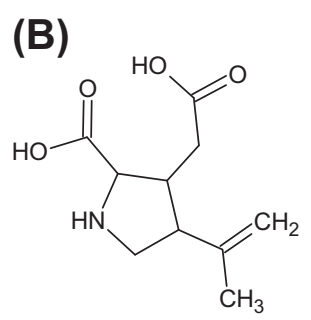

Kainic acid

FIGURE 110.3

Comparison of chemical structures of (A) the amino acid cucurbitin (3-amino-pyrrolidine-3-carboxylic acid) and (B) the nematicidal compound kainik acid. The similarity in chemical structure (the pyrrolidine ring) may underlie the similar mode of action of cucurbitin as an anthelmintic. 


\section{PART 2}

Effects of Specific Nuts and Seeds

anthelmintic action by inhibiting the synthesis of proteins and stopping development in helminths.

Terpenoid compounds (e.g., essential oils, saponins) are known to be active against a large range of organisms. Some of them are bioactive, whereas others can affect physical variables. Because they are a complex mixture of compounds, terpenoids can be effective against several targets. The triterpenic cucurbitacins can be toxic, purgative compounds, and are involved in insect resistance (Marie-Magdeleine et al., 2009). Terpenoids reduced the mobility and the consequent migration ability of ovine nematode larvae (Marie-Magdeleine et al., 2009). Furthermore, triterpenoids, saponins, and sterols are all antibacterial, antimicrobial, anticarcinogenic, and antifungal (Marie-Magdeleine et al., 2009). The complexity of the nature of these compounds and their chemical structures could enable interaction with multiple molecular targets at the various developmental stages of the parasites, and be responsible for the anthelmintic activity of the C. moschata seeds. The mode of action of these groups of compounds against nematodes and helminths may involve synergy (Marie-Magdeleine et al., 2009).

\section{ADVERSE EFFECTS AND REACTIONS (ALLERGIES AND TOXICITY)}

Ingestion of the internal part of seed given per os to 105 children infected with Enterobius vermicularis was effective, and had no side effects (TRAMIL, 1999). No side effects were observed when testing cucurbitin compared to a placebo on 53 persons for prostate hyperplasia over 3 months (TRAMIL, 1999). Low-level toxicity in dogs and humans was described for cucurbitin (TRAMIL, 1999).

\section{SUMMARY POINTS}

- The pumpkin Cucurbita moschata is an annual dicotyledonous vegetable, belonging to the Cucurbitaceae family. It is commonly cultivated worldwide.

- The seeds and fruits of C. moschata are edible; they are used as a medicinal plant for prostate and bladder problems, and as an anthelmintic, a galactogogue, and an anti-emetic.

- Pumpkin seed is used as a vermifuge in several countries, and C. moschata seed contains a wide range of bioactive compounds, some of which could possess anthelmintic properties, prompting experimental studies.

- Biological assays showed that the C. moschata seed has nematicidal, trematodicidal, taenicidal, and schistosomicidal effects.

- The non-proteic aminoacid cucurbitin (3-amino-pyrrolidine-3-carboxylic acid) is suspected to be the active principle. Cucurbitin was mostly reported to have no side effects, and only a weak level of toxicity was described in dogs and humans.

\section{References}

Atjanasuppat, K., Wongkham, W., Meepowpan, P., Kittakoop, P., Sobhon, P., Bartlett, A., et al. (2009). In vitro screening for anthelmintic and antitumour activity of ethnomedicinal plants from Thailand. Journal of Ethnopharmacology, 123, 475-482.

Beloin, N., Gbeassor, M., Akpagana, K., Hudson, J., De Soussa, K., Koumaglo, K., et al. (2005). Ethnomedicinal uses of Momordica charantia (Cucurbitaceae) in Togo and relation to its phytochemistry and biological activity. Journal of Ethnopharmacology, 96, 49-55.

Caili, F., Huan, S., \& Quanhong, L. (2006). A review on pharmacological activities and utilization technologies of pumpkin. Plant Foods for Human Nutrition, 61, 73-80.

Fang, S. D., Li, L. C., Niu, C. I., \& Tseng, K. F. (1961). Chemical studies on Cucurbita moschata Duch. I. The isolation and structural studies of cucurbitine, a new amino acid. Scientia Sinica, X 845-851.

Fournet, J. (2002). Flore illustrée des phanérogames de Guadeloupe et de Martinique. Trinité, Martinique: CIRAD-GONDWANA Editions.

Grubben, G. J. H., \& Denton, O. A. (Eds.). (2004). Plant resources of tropical Africa, Vol. 2: Vegetables. Wageningen, The Netherlands: PROTA Edition. 
Karamanukian. (1961). Comparative study of the commercial varieties of Cucurbita and their possible relation to the taenifugal activity of their seeds. MS thesis. Beirut, Lebanon: American University of Beirut.

Koike, K., Li, W., Liu, L., Hata, E., \& Nikaido, T. (2005). New phenolic glycosides from the seeds of Cucurbita moschata. Chemical \& Pharmaceutical Bulletin (Tokyo), 53, 225-228.

Leung, W.-T. W., Busson, F., \& Jardin, C. (1968). Food composition table for use in Africa. Rome, Italy: FAO.

Marie-Magdeleine, C. (2009). Etude des propriétés anthelminthiques de quelques ressources végétales tropicales pour un usage vétérinaire. PhD thesis, Université Antilles Guyane (in press).

Marie-Magdeleine, C., Hoste, H., Mahieu, M., Varo, H., \& Archimède, H. (2009). In vitro effects of Cucurbita moschata seed extracts on Haemonchus contortus. Veterinary Parasitology, 161, 99-105.

Mihranian, V. H., \& Abou-Chaar, C. I. (1968). Extraction, detection and estimation of cucurbitin in Cucurbita seeds. Lloydia, 31, 23-29.

Morton, J. (1981). Atlas of medicinal plants of Middle America. Springfield, IL: Charles C. Thomas.

Plotnikov, A. A., Karnaukhov, V. K., Ozeretskovskaia, N. N., Stromskaia, T. F., \& Firsova, R. A. (1972). Clinical trial of cucurbin (a preparation from pumpkin seeds) in cestodiasis. Klinicheskaia ispytaniia kukurbina (preparata iz semian tykvy) pri tsestodozakh. Medical Parazitol Parazite Bolezni, 41, 407-411.

Schenkel, E., Duez, P., \& Hanocq, M. (1992). Stereoselective determination of cucurbitine in Cucurbita spp. seeds by gas chromatography and gas chromatography-mass spectrometry. Journal of Chromatography, 625, 289-298.

Taylor, M., \& Brant, J. (2002). Trends in world cucurbit production, 1991 to 2001. In D. N. Maynard (Ed.), Cucurbitaceae (pp. 373-379). Alexandria, VA: ASHS Press.

TRAMIL (1999). Pharmacopée Caribéenne. Fort-de France, French West Indies: Editions Désormeaux, Edition L. Germosen-Robineau.

Veen, A. G., \& Collier, W. A. (1949). Stable palatable preparation of Laboe Marah (Cucurbita moschata). Dutch Patent 63,333, June 15. Chemical Abstracts, 43, 7198.

Vogel, V. J. (1990). American Indian medicine. Oklahoma, OH: University of Oklahoma Press. 